\title{
Job Analysis by Department in Clinical Practice for Realization of Legal Scope of Dental Hygienists: Focusing on Conservation, Pediatric Dentistry, Prosthodontics, Oral and Maxillofacial Surgery, and Implant Departments
}

\author{
Mi-Sook Yoon ${ }^{\dagger}$ \\ Department of Dental Hygiene, Shinhan University, Uijeongbu 11644, Korea
}

\begin{abstract}
Background: The objective of the present study was to specifically divide the various work performed by dental hygienists in clinical practice for legal amendments regarding problems associated with conflict between job roles and illegal delegation to establish key basic data for legislation and policy utilization for realization of legal scope of dental hygienists.

Methods: The study used work reports drafted based on research methods in the "Second Job Analysis Report on Dental Hygienists" researched by the Korean Health Personnel Licensing Examination Institute in 2012 and "Opinions of Dentists on Actual and Legal Work of Dental Hygienists," a report published by the Korean Dental Hygienists Association. Of these, the study focused on conservation dentistry, pediatric dentistry, prosthodontics, oral and maxillofacial surgery, and dental implant treatment, which make up some of the fields covered by dental hygiene practice, to investigate and analyzed work performed by clinical experience.

Results: Analysis of work actually performed in dental practice showed that for work related to 33 items presented in the study methods, the participants responded that they are currently performing such work or are likely to perform such work in the future, although there were differences by year. Investigation by type of workplace showed that dental hygienists working in university hospitals could perform the work presented if they had $\geq 5$ years of dental hygienist experience, whereas dental hygienists working in dental clinics or hospitals could perform simple duties in their first year and performed more diverse duties with greater degree of difficulty after their second to fourth year.

Conclusion: The reality that medical assistance during surgical operations and various procedures that is still being performed is no longer legally protected directly contradicts the needs in dental practice, and thus, there is the need to amend laws that are realistic by clearly recognizing the work of dental hygienists.
\end{abstract}

Key Words: Clinical dental practice, Dental assist, Dental hygienist, Legal scope

\section{Introduction}

South Korea adopted the dental hygienist system for the first time in 1965 and has continued to develop dental hygienists. Over the past 50 years with licenses issued by the Minister of Health and Welfare, dental hygienists have performed various work throughout dentistry together with dentists while undergoing quantitative expansion and changes in educational curriculum for 3- and 4-year programs. The length of program changed from 2 years to 3 years starting from 1994, followed by Yonsei University Wonju College of Medicine starting a 4-year program in 2002. As of December 2019, there are 82 educational institutions with dental hygiene program in South Korea with 5,190 enrollees. Moreover, there is an increasing trend in the number of licensed dental hygienists with 
4,890 licensed dental hygienists by $2020^{1)}$.

Up to now, the legal scope of dental hygienists consisted of eight duties related to prevention of dental and oral diseases and hygiene care, including installation and removal of arch wire; fluoride application; diagnostic intraoral radiography; temporary filling; installation of temporary attachments; removal of dental attachments; removal of dental deposits such as tartar; dental impressions; and others. In other words, their work is limited to work related to prevention of dental and oral diseases and hygiene care, which is quite different from the actual work performed in clinical dental practice ${ }^{2)}$.

Moreover, dental hygienists are regulated to perform their work as instructed by a dentist, but because medical assistance work is not clearly specified in the Enforcement Decree of the Medical Technologists, Etc. Act, some claim that such work is illegal. A study by Shin et al. ${ }^{3)}$ reported that nursing assistants were performing work within the legal scope of dental hygienists, including teeth cleaning and polishing $(91 \%)$; intraoral radiography (97\%); extraoral radiography $(94 \%)$; and dental caries prevention-related work such as application of fluoride and dental sealants $(55 \%)$. The study reported that because the work within the legal scope of dental hygienists was being performed at a high rate by nursing assistants, causing major conflict between job roles with dental hygienists. Although much time has passed and broadly defined work scope of dental hygienists has been specified through amendment of enforcement decree, confusion and problems with work and roles between oral healthcare personnel remain unresolved and dispute about work areas still continue.

With respect to problems with work areas that lead to dispute between job roles, nursing assistants were not allowed to perform some of the work that dental hygienists had been performing as the work scope of dental hygienists was specified by law, while differences in the interpretation of terms such as medical cooperation and assistance have led to dispute over work area, such as surgical assistance, measurement of vital signs, and injections. As a result, increase in legal disputes becomes inevitable regardless of the reality inside treatment rooms.

Therefore, more fundamental, realistic, and consistent legal and institutional measures are deemed necessary for the supply and demand of personnel throughout the entire field of dentistry ${ }^{4)}$. The reason is that fee-for-service in the national health insurance system divides the overall work performed by dental hygienists, such as medical assistance work, by the procedure performed to determine the labor cost, whereas laws determine the work scope of dental hygienists on a case-by-case basis and take the paradoxical position of having to determine the work scope based on cases penalized for deviating from the work scope.

The current dental hygiene curriculum in South Korea includes broad range of area of concentration and related courses. However, the work scope in clinical practice is not being sufficiently reflected in laws, and as a result, illegal delegation and illegal controversies continue, which makes it difficult for dental hygienists to provide high-quality dental care services. Legal amendments should be made based on systematic review and determination of validity by the government first instead of prioritizing consensus gathering between job roles ${ }^{5)}$.

Dental hygienists currently perform a significant amount of medical assistance work, in addition to their legally defined work. Therefore, to prevent them from becoming potential lawbreakers in some cases, depending on the authoritative interpretation by the Ministry of Health and Welfare, the gap that currently exists between actual clinical practice and relevant regulations must be eliminated as much as possible and legal amendment must take place from a macro perspective ${ }^{6}$.

Accordingly, the researchers of the present study specifically divided and analyzed various work performed by dental hygienists in clinical practice for legal amendments regarding problems associated with conflict between job roles and illegal delegation. As part of that work scope, the study focused on conservation dentistry, pediatric dentistry, prosthodontics, oral and maxillofacial surgery, and dental implant treatment in conducting job survey and correlation analysis by clinical experience and workplace to establish basic data needed for legislation and policy utilization for realization of legal scope of dental hygienists. 


\section{Materials and Methods}

\section{Materials}

The study recruited 250 dental hygienists from university hospitals, dental hospitals, and dental clinics located in Seoul and Gyeonggi region that were randomly selected. The recruits were requested for cooperation through an explanation about the questionnaire survey and a self-reporting questionnaire was distributed to 220 dental hygienists who consented to participate in the study. The data collection period was between June 2019 and February 2020. After excluding 25 sets for insufficient responses, data from 195 participants were analyzed.

\section{Methods}

The study used a job survey tool that was edited based on the job description contained in the "Second Job Analysis Report on Dental Hygienists,"7) which was researched by the Korean Health Personnel Licensing Examination Institute in 2012 targeting active dental hygienists and instructors, and "A study on the dentist's opinion on the actual work and legal work of dental hygienists," $"$ which is a report published by the Korean Dental Hygienists Association.

The questionnaire consisted of five items regarding the general characteristics of participants, including sex, graduation year, clinical experience, workplace, and department. In addition, some parts of dental hygiene practice were extracted for the items that were constructed by dividing the duties of dental hygienists based on dental hygiene care process, resulting in 14 items on duties related to prosthodontics and dental implant treatment; 12 items on duties related to conservation dentistry and pediatric dentistry; and seven items on duties related to oral and maxillofacial surgery. Work experience was divided into 1 year, $2 \sim 4$ years, $\geq 5$ years, and likely to perform in the future based on the classification criteria given in the methods section of "A study on the dentist's opinion on the actual work and legal work of dental hygienists"8). The goal was to prove the work of dental hygienists by comparison with the findings in the present study. The participants were instructed to mark 'likely to perform in the future' if they are not currently performing that work, but may perform such work in the future as their work experience grows or they are transferred to a different department.

Collected data were analyzed using IBM SPSS Statistics for Windows, ver. 25.0 (IBM Corp., Armonk, NY, USA). With respect to the analytic technique, frequency and percentage were calculated for the general characteristics of participants and duties performed during patient care. Moreover, chi-squared test was performed with statistical significance level of 0.05 to investigate the associations with clinical experience of dental hygienists with respect to job performance.

\section{Results}

\section{General characteristics of participants}

The general characteristics of participants were as

Table 1. General Characteristics of Participants

\begin{tabular}{|c|c|c|}
\hline \multicolumn{2}{|c|}{ Division } & Frequency \\
\hline \multirow[t]{2}{*}{ Sex } & Male & $6(3.1)$ \\
\hline & Female & 189 (96.9) \\
\hline \multirow[t]{5}{*}{ Graduation year } & Before 2005 & $27(13.8)$ \\
\hline & $2005 \sim 2009$ & $17(8.7)$ \\
\hline & $2010 \sim 2015$ & $52(26.7)$ \\
\hline & $2016 \sim 2018$ & $72(36.9)$ \\
\hline & After 2019 & $27(13.8)$ \\
\hline \multirow[t]{3}{*}{ Clinical experience (y) } & 1 & $31(15.9)$ \\
\hline & $2 \sim 4$ & $74(37.9)$ \\
\hline & $\geq 5$ & $90(46.2)$ \\
\hline \multirow[t]{3}{*}{ Workplace } & University hospital level & $31(15.9)$ \\
\hline & Dental hospital level & $89(45.6)$ \\
\hline & Dental clinics & $75(38.5)$ \\
\hline \multirow[t]{14}{*}{ Department } & Not divided & $32(16.4)$ \\
\hline & Orthodontics & $31(15.9)$ \\
\hline & General dentistry & $9(4.6)$ \\
\hline & Diagnosis/treatment & $7(3.6)$ \\
\hline & Prosthodontics & $30(15.4)$ \\
\hline & Periodontics & $17(8.7)$ \\
\hline & Oral surgery & $17(8.7)$ \\
\hline & Conservation dentistry & $14(7.2)$ \\
\hline & Pediatric dentistry & $10(5.1)$ \\
\hline & Administration & $2(1)$ \\
\hline & Oral medicine & $5(2.6)$ \\
\hline & Oral hygiene & $3(1.5)$ \\
\hline & Dental implants & $11(5.6)$ \\
\hline & Others & 7 (3.6) \\
\hline Total & & $195(100.0)$ \\
\hline
\end{tabular}

Values are presented as number (\%). 
shown in Table 1.

Among a total of 195 participants, females accounted for the significant majority with $96.9 \%$ and males accounted for 3.1\%. With respect to graduation year, 2016 2018 was the most common response $(36.9 \%)$, followed in order by $2010 \sim 2015$ (26.7\%), before 2005 (13.8\%), after

Table 2. Duties Performed in Conservation Dentistry and Pediatric Dentistry

\begin{tabular}{|c|c|c|c|c|c|c|c|}
\hline \multicolumn{3}{|c|}{ Division } & \multirow{2}{*}{$\begin{array}{c}\begin{array}{c}\text { University } \\
\text { hospital level }\end{array} \\
5(16.1)\end{array}$} & \multirow{2}{*}{$\begin{array}{c}\begin{array}{c}\text { Dental } \\
\text { hospital level }\end{array} \\
22(24.7)\end{array}$} & \multirow{2}{*}{$\begin{array}{c}\text { Dental clinics } \\
31(41.3)\end{array}$} & \multirow{2}{*}{$\begin{array}{c}\text { Total } \\
58(29.7)\end{array}$} & \multirow{2}{*}{$\begin{array}{r}\mathrm{p} \text {-value } \\
0.046\end{array}$} \\
\hline & Rubber dam & 1 & & & & & \\
\hline performed in & isolation $(\mathrm{y})$ & $2 \sim 4$ & $9(29.0)$ & $26(29.2)$ & $22(29.3)$ & $57(29.2)$ & \\
\hline conservation & & $\geq 5$ & $12(38.7)$ & $22(24.7)$ & $15(20.0)$ & $49(25.1)$ & \\
\hline $\begin{array}{l}\text { dentistry/pedia } \\
\text { tric dentistry }\end{array}$ & & $\begin{array}{l}\text { Likely to perform } \\
\text { in the future }\end{array}$ & $5(16.1)$ & $19(21.3)$ & $7(9.3)$ & $31(15.9)$ & \\
\hline & \multirow{4}{*}{$\begin{array}{l}\text { Matrix band } \\
\text { technique }(y)\end{array}$} & 1 & $5(16.1)$ & $13(14.6)$ & $27(36.0)$ & $45(23.1)$ & 0.006 \\
\hline & & $2 \sim 4$ & $8(25.8)$ & $24(27.0)$ & $23(30.7)$ & $55(28.2)$ & \\
\hline & & $\geq 5$ & $10(32.3)$ & $21(23.6)$ & $15(20.0)$ & $46(23.6)$ & \\
\hline & & $\begin{array}{l}\text { Likely to perform } \\
\text { in the future }\end{array}$ & $8(25.8)$ & $31(34.8)$ & $10(13.3)$ & $49(25.1)$ & \\
\hline & \multirow{4}{*}{$\begin{array}{r}\text { Temporary } \\
\text { filling }(\mathrm{y})\end{array}$} & 1 & $4(12.9)$ & $21(23.6)$ & $34(45.3)$ & $59(30.3)$ & 0.001 \\
\hline & & $2 \sim 4$ & $8(25.8)$ & $30(33.7)$ & $23(30.7)$ & $61(31.3)$ & \\
\hline & & $\geq 5$ & $12(38.7)$ & $27(30.3)$ & $16(21.3)$ & $55(28.2)$ & \\
\hline & & $\begin{array}{l}\text { Likely to perform } \\
\text { in the future }\end{array}$ & $7(22.6)$ & $11(12.4)$ & $2(2.7)$ & $20(10.3)$ & \\
\hline & \multirow{4}{*}{$\begin{array}{l}\text { Assistance for } \\
\text { restorative } \\
\text { treatment }(\mathrm{y})\end{array}$} & 1 & $6(19.4)$ & $23(25.8)$ & $34(45.3)$ & $63(32.3)$ & 0.002 \\
\hline & & $2 \sim 4$ & $6(19.4)$ & $29(32.6)$ & $24(32.0)$ & $59(30.3)$ & \\
\hline & & $\geq 5$ & $13(41.9)$ & $25(28.1)$ & $16(21.3)$ & $54(27.7)$ & \\
\hline & & $\begin{array}{l}\text { Likely to perform } \\
\text { in the future }\end{array}$ & $6(19.4)$ & $12(13.5)$ & $1(1.3)$ & $19(9.7)$ & \\
\hline & \multirow{4}{*}{$\begin{array}{l}\text { Pulp vitality } \\
\text { test }(\mathrm{y})\end{array}$} & 1 & $4(12.9)$ & $11(12.4)$ & $19(25.3)$ & $34(17.4)$ & 0.003 \\
\hline & & $2 \sim 4$ & $8(25.8)$ & $17(19.1)$ & $25(33.3)$ & $50(25.6)$ & \\
\hline & & $\geq 5$ & $10(32.3)$ & $16(18.0)$ & $15(20.0)$ & $41(21.0)$ & \\
\hline & & $\begin{array}{l}\text { Likely to perform } \\
\text { in the future }\end{array}$ & $9(29.0)$ & $45(50.6)$ & $16(21.3)$ & $70(35.9)$ & \\
\hline & \multirow{4}{*}{$\begin{array}{l}\text { Assistance for pulp } \\
\text { treatment }(\mathrm{y})\end{array}$} & 1 & $5(16.1)$ & $23(25.8)$ & $32(42.7)$ & $60(30.8)$ & 0.006 \\
\hline & & $2 \sim 4$ & $8(25.8)$ & $25(28.1)$ & $24(32.0)$ & $57(29.2)$ & \\
\hline & & $\geq 5$ & $13(41.9)$ & $25(28.1)$ & $17(22.7)$ & $55(28.2)$ & \\
\hline & & $\begin{array}{l}\text { Likely to perform } \\
\text { in the future }\end{array}$ & $5(16.1)$ & $16(18.0)$ & $2(2.7)$ & $23(11.8)$ & \\
\hline & \multirow{4}{*}{$\begin{array}{l}\text { Teeth whitening } \\
\text { treatment }(\mathrm{y})\end{array}$} & 1 & $2(6.5)$ & $3(3.4)$ & $13(17.3)$ & $18(9.2)$ & $<0.001$ \\
\hline & & $2 \sim 4$ & $11(35.5)$ & $20(22.5)$ & $37(49.3)$ & $68(34.9)$ & \\
\hline & & $\geq 5$ & $10(32.3)$ & $19(21.3)$ & $17(22.7)$ & $46(23.6)$ & \\
\hline & & $\begin{array}{l}\text { Likely to perform } \\
\text { in the future }\end{array}$ & $8(25.8)$ & $47(52.8)$ & $8(10.7)$ & $63(32.3)$ & \\
\hline & \multirow{4}{*}{$\begin{array}{c}\text { Assistance for } \\
\text { primary tooth } \\
\text { extraction }(y)\end{array}$} & 1 & $6(19.4)$ & $24(27.0)$ & $34(45.3)$ & $64(32.8)$ & 0.022 \\
\hline & & $2 \sim 4$ & $9(29.0)$ & $31(34.8)$ & $24(32.0)$ & $64(32.8)$ & \\
\hline & & $\geq 5$ & $12(38.7)$ & $26(29.2)$ & $16(21.3)$ & $54(27.7)$ & \\
\hline & & $\begin{array}{l}\text { Likely to perform } \\
\text { in the future }\end{array}$ & $4(12.9)$ & $8(9.0)$ & $1(1.3)$ & $13(6.7)$ & \\
\hline & \multirow{4}{*}{$\begin{array}{l}\text { Assistance for } \\
\text { prosthodontic } \\
\text { treatment of } \\
\text { primary teeth }(\mathrm{y})\end{array}$} & 1 & $5(16.1)$ & $16(18.0)$ & $30(40.0)$ & $51(26.2)$ & $<0.001$ \\
\hline & & $2 \sim 4$ & $10(32.3)$ & $16(18.0)$ & $25(33.3)$ & $51(26.2)$ & \\
\hline & & $\geq 5$ & $12(38.7)$ & $20(22.5)$ & $16(21.3)$ & $48(24.6)$ & \\
\hline & & $\begin{array}{l}\text { Likely to perform } \\
\text { in the future }\end{array}$ & $4(12.9)$ & $37(41.6)$ & $4(5.3)$ & $45(23.1)$ & \\
\hline
\end{tabular}


Table 2. Continued

\begin{tabular}{|c|c|c|c|c|c|c|c|}
\hline \multicolumn{3}{|c|}{ Division } & \multirow{2}{*}{$\begin{array}{c}\begin{array}{c}\text { University } \\
\text { hospital level }\end{array} \\
5(16.1)\end{array}$} & \multirow{2}{*}{$\begin{array}{c}\begin{array}{c}\text { Dental } \\
\text { hospital level }\end{array} \\
9(10.1)\end{array}$} & \multirow{2}{*}{$\begin{array}{c}\text { Dental clinics } \\
26(34.7)\end{array}$} & \multirow{2}{*}{$\begin{array}{c}\text { Total } \\
40(20.5)\end{array}$} & \multirow{2}{*}{$\begin{array}{l}\mathrm{p} \text {-value } \\
<0.001\end{array}$} \\
\hline Duties & Preparation for & 1 & & & & & \\
\hline performed in & dental fenestration & $2 \sim 4$ & $9(29.0)$ & $16(18.0)$ & $16(21.3)$ & $41(21.0)$ & \\
\hline conservation & (y) & $\geq 5$ & $12(38.7)$ & $16(18.0)$ & $11(14.7)$ & $39(20.0)$ & \\
\hline $\begin{array}{l}\text { dentistry/pedia } \\
\text { tric dentistry }\end{array}$ & & $\begin{array}{l}\text { Likely to perform } \\
\text { in the future }\end{array}$ & $5(16.1)$ & $48(53.9)$ & $22(29.3)$ & $75(38.5)$ & \\
\hline & \multirow{4}{*}{$\begin{array}{l}\text { Preventive } \\
\text { orthodontic } \\
\text { treatment } \\
\text { training (y) }\end{array}$} & 1 & $5(16.1)$ & $12(13.5)$ & $19(25.3)$ & $36(18.5)$ & $<0.001$ \\
\hline & & $2 \sim 4$ & $8(25.8)$ & $17(19.1)$ & $31(41.3)$ & $56(28.7)$ & \\
\hline & & $\geq 5$ & $15(48.4)$ & $20(22.5)$ & $14(18.7)$ & $49(25.1)$ & \\
\hline & & $\begin{array}{l}\text { Likely to perform } \\
\text { in the future }\end{array}$ & $3(9.7)$ & $40(44.9)$ & $11(14.7)$ & $54(27.7)$ & \\
\hline & \multirow{4}{*}{$\begin{array}{l}\text { Assistance for } \\
\text { behavior } \\
\text { management of } \\
\text { pediatric patients } \\
\text { (y) }\end{array}$} & 1 & $6(19.4)$ & $13(14.6)$ & $22(29.3)$ & $41(21.0)$ & $<0.001$ \\
\hline & & $2 \sim 4$ & $8(25.8)$ & $26(29.2)$ & $30(40.0)$ & $64(32.8)$ & \\
\hline & & $\geq 5$ & $13(41.9)$ & $19(21.3)$ & $16(21.3)$ & $48(24.6)$ & \\
\hline & & $\begin{array}{l}\text { Likely to perform } \\
\text { in the future }\end{array}$ & $4(12.9)$ & $31(34.8)$ & $7(9.3)$ & $42(21.5)$ & \\
\hline Total & & & $31(15.9)$ & 89 (45.6) & $75(38.5)$ & $195(100.0)$ & \\
\hline
\end{tabular}

Values are presented as number (\%).

$2019(13.8 \%)$, and $2005 \sim 2009$ (8.7\%). With respect to clinical experience, $\geq 5$ years was the most common response $(46.2 \%)$, followed in order by $2 \sim 4$ years $(37.9 \%)$ and first year $(15.9 \%)$. With respect to workplace, dental hospital was the most common response (45.6\%), followed in order by dental clinic (38.5\%) and university hospital (15.9\%). With respect to work department, orthodontics was the most common response (15.9\%), followed in order by prosthodontics $(15.4 \%)$, periodontics $(8.7 \%)$, oral surgery $(8.7 \%)$, conservation dentistry (7.2\%), dental implants (5.6\%), and pediatric dentistry $(5.1 \%)$. In addition, $16.4 \%$ of the responses indicated no division of departments.

\section{Duties performed in conservation dentistry and pediatric dentistry}

Table 2 shows the results of duties performed by dental hygienists in conservation dentistry and pediatric dentistry.

Rubber dam isolation was performed most often by those with work experience of 1 year (29.7\%), followed in order by $2 \sim 4$ years $(29.2 \%), \geq 5$ years $(25.1 \%)$, and likely to perform in the future $(15.9 \%)$. With respect to workplace, there were significant differences in who most often performed rubber dam isolation among different workplaces with $\geq 5$ years, $2 \sim 4$ years, and 1 year being the most common response for university hospitals, dental hospitals, and dental clinics, respectively $(\mathrm{p}<0.05)$.

Matrix band technique was performed most often by those with work experience of $2 \sim 4$ years (28.2\%), followed in order by likely to perform in the future $(25.1 \%), \geq 5$ years $(23.6 \%)$, and 1 year $(23.1 \%)$. With respect to workplace, there were significant differences in who most often performed matrix band technique among different workplaces with $\geq 5$ years, likely to perform in the future, and 1 year being the most common response for university hospitals, dental hospitals, and dental clinics, respectively $(\mathrm{p}<0.01)$.

Temporary fillings were performed most often by those with work experience of $2 \sim 4$ years $(31.3 \%)$, followed in order by 1 year $(30.3 \%), \geq 5$ years $(28.2 \%)$, and likely to perform in the future $(10.3 \%)$. With respect to workplace, there were significant differences in who most often performed temporary fillings among different workplaces with $\geq 5$ years, $2 \sim 4$ years, and 1 year being the most common response for university hospitals, dental hospitals, and dental clinics, respectively $(\mathrm{p}<0.01)$.

Assistance for restorative treatment was performed most often by those with work experience of 1 year $(32.3 \%)$, followed in order by $2 \sim 4$ years $(30.3 \%), \geq 5$ years $(27.7 \%)$, and likely to perform in the future $(9.7 \%)$. 
With respect to understanding radiography equipment, there were significant differences among different workplaces with $\geq 5$ years, $2 \sim 4$ years, and 1 year being the most common response for university hospitals, dental hospitals, and dental clinics, respectively $(\mathrm{p}<0.01)$.

With respect to pulp vitality test, the most common response was likely to perform in the future $(35.9 \%)$, followed in order by $2 \sim 4$ years $(25.6 \%), \geq 5$ years (21.0\%), and 1 year (17.4\%). With respect to workplace, there were significant differences in who most often performed pulp vitality tests among different workplaces with $\geq 5$ years, likely to perform in the future, and $2 \sim 4$ years being the most common response for university hospitals, dental hospitals, and dental clinics, respectively $(\mathrm{p}<0.01)$.

Assistance for pulp treatment was performed most often by those with work experience of 1 year $(30.8 \%)$, followed in order by $2 \sim 4$ years $(29.2 \%), \geq 5$ years (28.2\%), and likely to perform in the future (11.8\%). With respect to workplace, there were significant differences in who most often performed assistance for pulp treatment among different workplaces with $\geq 5$ years, $2 \sim 4$ and $\geq 5$ years, and 1 year being the most common response for university hospitals, dental hospitals, and dental clinics, respectively $(\mathrm{p}<0.01)$.

Teeth whitening treatment was performed most often by those with work experience of $2 \sim 4$ years (34.9\%), followed in order by likely to perform in the future $(32.3 \%), \geq 5$ years $(23.6 \%)$, and 1 year $(9.2 \%)$. With respect to workplace, there were significant differences in who most often performed assistance for teeth whitening treatment among different workplaces with $2 \sim 4$ years, likely to perform in the future, and $2 \sim 4$ years being the most common response for university hospitals, dental hospitals, and dental clinics, respectively $(\mathrm{p}<0.001)$.

Assistance for primary tooth extraction was performed most often by those with work experience of 1 year and $2 \sim 4$ years $(32.8 \%$ each), followed in order by $\geq 5$ years $(27.7 \%)$ and likely to perform in the future $(6.7 \%)$. With respect to workplace, there were significant differences in who most often performed assistance for primary tooth extraction among different workplaces with $\geq 5$ years, $2 \sim 4$ years, and 1 year being the most common response for university hospitals, dental hospitals, and dental clinics, respectively $(\mathrm{p}<0.05)$.

Assistance for prosthodontic treatment of primary teeth was performed most often by those with work experience of 1 year and $2 \sim 4$ years (26.2\% each), followed in order by $\geq 5$ years $(24.6 \%)$ and likely to perform in the future $(23.1 \%)$. With respect to workplace, there were significant differences in who most often performed assistance for prosthodontic treatment of primary teeth among different workplaces with $\geq 5$ years, likely to perform in the future, and 1 year being the most common response for university hospitals, dental hospitals, and dental clinics, respectively $(\mathrm{p}<0.001)$.

For preparation for dental fenestration, the most common response was likely to perform in the future $(38.5 \%)$, followed in order by $2 \sim 4$ years $(21.0 \%), 1$ year $(20.5 \%)$, and $\geq 5$ years $(20.0 \%)$. With respect to workplace, there were significant differences in who most often performed dental fenestration among different workplaces with $\geq 5$ years, likely to perform in the future, and 1 year being the most common response for university hospitals, dental hospitals, and dental clinics, respectively $(\mathrm{p}<0.001)$.

For preventive orthodontic treatment training, the most common response was $2 \sim 4$ years $(28.7 \%)$, followed in order by likely to perform in the future $(27.7 \%), \geq 5$ years $(25.1 \%)$, and 1 year $(18.5 \%)$. With respect to workplace, there were significant differences in preventive orthodontic treatment training among different workplaces with $\geq 5$ years, likely to perform in the future, and $2 \sim 4$ years being the most common response for university hospitals, dental hospitals, and dental clinics, respectively $(\mathrm{p}<0.001)$.

Assistance for behavior management of pediatric patients was performed most often by those with work experience of $2 \sim 4$ years $(32.8 \%)$, followed in order by $\geq 5$ years $(24.6 \%)$, likely to perform in the future $(21.5 \%)$, and 1 year $21.0 \%$. With respect to workplace, there were significant differences in who most often performed assistance for behavior management of pediatric patients among different workplaces with $\geq 5$ years, likely to perform in the future, and $2 \sim 4$ years being the most common response for university hospitals, dental hospitals, and dental clinics, respectively $(\mathrm{p}<0.001)$. 


\section{Duties performed in prosthodontics}

Table 3 shows the results of duties performed by dental hygienists in prosthodontics. Gingival retraction was performed most often by those with work experience of $2 \sim 4$ years $(36.4 \%)$, followed in order by $\geq 5$ years
(27.2\%), 1 year $(23.1 \%)$, and likely to perform in the future $(13.3 \%)$. With respect to workplace, $\geq 5$ years was the most common response for university hospitals and $2 \sim 4$ years was the most common response for dental hospitals and dental clinics, but the differences were not

Table 3. Duties Performed in Prosthodontics

\begin{tabular}{|c|c|c|c|c|c|c|c|}
\hline \multicolumn{3}{|c|}{ Division } & \multirow{2}{*}{$\begin{array}{c}\begin{array}{c}\text { University } \\
\text { hospital level }\end{array} \\
6(19.4)\end{array}$} & \multirow{2}{*}{$\begin{array}{c}\begin{array}{c}\text { Dental } \\
\text { hospital level }\end{array} \\
15(16.9)\end{array}$} & \multirow{2}{*}{$\begin{array}{c}\begin{array}{c}\text { Dental } \\
\text { clinics }\end{array} \\
24(32.0)\end{array}$} & \multirow{2}{*}{$\begin{array}{c}\text { Total } \\
45(23.1)\end{array}$} & \multirow{2}{*}{$\begin{array}{r}\text { p-value } \\
0.127\end{array}$} \\
\hline \multirow{32}{*}{$\begin{array}{l}\text { Duties performed } \\
\text { in prosthodontics }\end{array}$} & \multirow{4}{*}{$\begin{array}{l}\text { Gingival } \\
\quad \text { retraction }(\mathrm{y})\end{array}$} & 1 & & & & & \\
\hline & & $2 \sim 4$ & $8(25.8)$ & $34(38.2)$ & $29(38.7)$ & $71(36.4)$ & \\
\hline & & $\geq 5$ & $12(38.7)$ & $26(29.2)$ & $15(20.0)$ & $53(27.2)$ & \\
\hline & & $\begin{array}{l}\text { Likely to perform } \\
\text { in the future }\end{array}$ & $5(16.1)$ & $14(15.7)$ & $7(9.3)$ & $26(13.3)$ & \\
\hline & \multirow{4}{*}{$\begin{array}{l}\text { Fabrication of } \\
\text { temporary crowns }(y)\end{array}$} & 1 & $6(19.4)$ & $9(10.1)$ & $26(34.7)$ & $41(21.0)$ & $<0.001$ \\
\hline & & $2 \sim 4$ & $8(25.8)$ & $34(38.2)$ & $31(41.3)$ & $73(37.4)$ & \\
\hline & & $\geq 5$ & $11(35.5)$ & $26(29.2)$ & $16(21.3)$ & $53(27.2)$ & \\
\hline & & $\begin{array}{l}\text { Likely to perform } \\
\text { in the future }\end{array}$ & $6(19.4)$ & $20(22.5)$ & $2(2.7)$ & $28(14.4)$ & \\
\hline & \multirow{4}{*}{$\begin{array}{l}\text { Assistance for fixed } \\
\text { prosthodontic } \\
\text { treatment }(y)\end{array}$} & 1 & $9(29.0)$ & $15(16.9)$ & $35(46.7)$ & $59(30.3)$ & $<0.001$ \\
\hline & & $2 \sim 4$ & $5(16.1)$ & $29(32.6)$ & $23(30.7)$ & $57(29.2)$ & \\
\hline & & $\geq 5$ & $12(38.7)$ & $25(28.1)$ & $15(20.0)$ & $52(26.7)$ & \\
\hline & & $\begin{array}{l}\text { Likely to perform } \\
\text { in the future }\end{array}$ & $5(16.1)$ & $20(22.5)$ & $2(2.7)$ & $27(13.8)$ & \\
\hline & \multirow{4}{*}{$\begin{array}{l}\text { Assistance for } \\
\text { removable } \\
\text { prosthodontic } \\
\text { treatment (y) }\end{array}$} & 1 & $9(29.0)$ & $15(16.9)$ & $34(45.3)$ & $58(29.7)$ & $<0.001$ \\
\hline & & $2 \sim 4$ & $5(16.1)$ & $22(24.7)$ & $24(32.0)$ & $51(26.2)$ & \\
\hline & & $\geq 5$ & $12(38.7)$ & $25(28.1)$ & $15(20.0)$ & $52(26.7)$ & \\
\hline & & $\begin{array}{l}\text { Likely to perform } \\
\text { in the future }\end{array}$ & $5(16.1)$ & $27(30.3)$ & $2(2.7)$ & $34(17.4)$ & \\
\hline & \multirow{4}{*}{$\begin{array}{l}\text { Fabrication of } \\
\text { individual trays }(\mathrm{y})\end{array}$} & 1 & 4 (12.9) & $3(3.4)$ & $13(17.3)$ & $20(10.3)$ & $<0.001$ \\
\hline & & $2 \sim 4$ & $7(22.6)$ & $16(18.0)$ & $30(40.0)$ & $53(27.2)$ & \\
\hline & & $\geq 5$ & $9(29.0)$ & $17(19.1)$ & $15(20.0)$ & $41(21.0)$ & \\
\hline & & $\begin{array}{l}\text { Likely to perform } \\
\text { in the future }\end{array}$ & $11(35.5)$ & $53(59.6)$ & $17(22.7)$ & $81(41.5)$ & \\
\hline & \multirow{4}{*}{$\begin{array}{l}\text { Dental shade } \\
\text { selection }(y)\end{array}$} & 1 & $5(16.1)$ & $13(14.6)$ & $23(30.7)$ & $41(21.0)$ & $<0.001$ \\
\hline & & $2 \sim 4$ & $6(19.4)$ & $30(33.7)$ & $34(45.3)$ & $70(35.9)$ & \\
\hline & & $\geq 5$ & $10(32.3)$ & $25(28.1)$ & $16(21.3)$ & $51(26.2)$ & \\
\hline & & $\begin{array}{l}\text { Likely to perform } \\
\text { in the future }\end{array}$ & $10(32.3)$ & $21(23.6)$ & $2(2.7)$ & $33(16.9)$ & \\
\hline & \multirow{4}{*}{$\begin{array}{l}\text { Application/removal } \\
\text { of prosthesis }(\mathrm{y})\end{array}$} & 1 & $7(22.6)$ & $17(19.1)$ & $25(33.3)$ & $49(25.1)$ & 0.022 \\
\hline & & $2 \sim 4$ & $7(22.6)$ & $31(34.8)$ & $31(41.3)$ & $69(35.4)$ & \\
\hline & & $\geq 5$ & $9(29.0)$ & $26(29.2)$ & $15(20.0)$ & $50(25.6)$ & \\
\hline & & $\begin{array}{l}\text { Likely to perform } \\
\text { in the future }\end{array}$ & $8(25.8)$ & $15(16.9)$ & $4(5.3)$ & $27(13.8)$ & \\
\hline & \multirow{4}{*}{$\begin{array}{l}\text { Management of } \\
\text { individual } \\
\text { prosthesis (y) }\end{array}$} & 1 & $7(22.6)$ & $10(11.2)$ & $22(29.3)$ & $39(20.0)$ & 0.001 \\
\hline & & $2 \sim 4$ & $7(22.6)$ & $31(34.8)$ & $33(44.0)$ & $71(36.4)$ & \\
\hline & & $\geq 5$ & $12(38.7)$ & $24(27.0)$ & $15(20.0)$ & $51(26.2)$ & \\
\hline & & $\begin{array}{l}\text { Likely to perform } \\
\text { in the future }\end{array}$ & $5(16.1)$ & $24(27.0)$ & $5(6.7)$ & $34(17.4)$ & \\
\hline Total & & & $31(15.9)$ & $89(45.6)$ & $75(38.5)$ & 195 (100.0) & \\
\hline
\end{tabular}

Values are presented as number (\%). 
significant.

Fabrication of temporary crowns was performed most often by those with work experience of $2 \sim 4$ years (37.4\%), followed in order by $\geq 5$ years $(27.2 \%)$, 1 year $(21.0 \%)$, and likely to perform in the future $(14.4 \%)$. With respect to workplace, there were significant differences in who most often performed fabrication of temporary crowns among different workplaces with $\geq 5$ years being the most common response for university hospitals and $2 \sim 4$ years being the most common response for dental hospitals and dental clinics $(\mathrm{p}<0.001)$.

Assistance for fixed prosthodontic treatment was performed most often by those with work experience of 1 year $(30.3 \%)$, followed in order by $2 \sim 4$ years $(29.2 \%)$, $\geq 5$ years $(26.7 \%)$, and likely to perform in the future (13.8\%). With respect to workplace, there were significant differences in who most often performed assistance for fixed prosthodontic treatment among different workplaces with $\geq 5$ years, $2 \sim 4$ years, and 1 year being the most common response for university hospitals, dental hospitals, and dental clinics, respectively $(\mathrm{p}<0.001)$.

Assistance for removable prosthodontic treatment was performed most often by those with work experience of 1 year $(29.7 \%)$, followed in order by $\geq 5$ years $(26.7 \%), 2 \sim$ 4 years $(26.2 \%)$, and likely to perform in the future (17.4\%). With respect to workplace, there were significant differences in who most often performed assistance for removal prosthodontic treatment among different workplaces with $\geq 5$ years, likely to perform in the future, and 1 year being the most common response for university hospitals, dental hospitals, and dental clinics, respectively $(\mathrm{p}<0.001)$.

For fabrication of individual trays, the most common response was likely to perform in the future $(41.5 \%)$, followed in order by $2 \sim 4$ years $(27.2 \%), \geq 5$ years $(21.0 \%)$, and 1 year $(10.3 \%)$. With respect to workplace, there were significant differences in who most often performed fabrication of individual trays among different workplaces with likely to perform in the future being the most common response for university hospitals and dental hospitals and $2 \sim 4$ years being the most common response for dental clinics $(\mathrm{p}<0.001)$.

Dental shade selection was performed most often by those with work experience of $2 \sim 4$ years $(35.9 \%)$, followed in order by $\geq 5$ years $(26.2 \%), 1$ year $(21.0 \%)$, and likely to perform in the future $(16.9 \%)$. With respect to workplace, there were significant differences in who most often performed dental shade selection among different workplaces with $\geq 5$ years and likely to perform in the future being the most common responses for university hospitals and $2 \sim 4$ years being the most common response for dental hospitals and dental clinics $(\mathrm{p}<$ 0.001).

Application/removal of prosthesis and management of individual prosthesis were performed most often by those with work experience of $2 \sim 4$ years $(35.4 \%$ and $36.4 \%$, respectively), followed in order by $\geq 5$ years $(25.6 \%$ and $26.2 \%$, respectively), 1 year $(25.1 \%$ and $20.0 \%$, respectively), and likely to perform in the future $(13.8 \%$ and $17.4 \%$, respectively). With respect to workplace, there were significant differences in who most often performed application/removal of prosthesis and management of individual prosthesis among different workplaces with $\geq$ 5 years and likely to perform in the future being the most common responses for university hospitals and $2 \sim 4$ years being the most common response for dental hospitals and dental clinics $(\mathrm{p}<0.01)$.

\section{Duties performed in oral and maxillofacial surgery}

Table 4 shows the results of duties performed by dental hygienists in oral and maxillofacial surgery.

Preparation for tooth extraction was performed most often by those with work experience of 1 year $(38.5 \%)$, followed in order by $2 \sim 4$ years $(28.7 \%), \geq 5$ years $(27.7 \%)$, and likely to perform in the future $(5.1 \%)$. With respect to workplace, there were significant differences in who most often performed preparation for tooth extraction among different workplaces with $\geq 5$ years, $2 \sim 4$ years, and 1 year being the most common response for university hospitals, dental hospitals, and dental clinics, respectively $(\mathrm{p}<0.05)$.

For preparation for biopsy, the most common response was likely to perform in the future $(37.9 \%)$, followed in order by 1 year $(25.1 \%), \geq 5$ years $(20.0 \%)$, and $2 \sim 4$ years $(16.9 \%)$. With respect to workplace, there were significant differences in who most often performed 
Table 4. Duties Performed in Oral and Maxillofacial Surgery

\begin{tabular}{|c|c|c|c|c|c|c|c|}
\hline \multicolumn{3}{|c|}{ Division } & \multirow{2}{*}{$\begin{array}{c}\begin{array}{c}\text { University } \\
\text { hospital level }\end{array} \\
8(25.8)\end{array}$} & \multirow{2}{*}{$\begin{array}{c}\begin{array}{c}\text { Dental hospital } \\
\text { level }\end{array} \\
27(30.3)\end{array}$} & \multirow{2}{*}{$\begin{array}{c}\text { Dental clinics } \\
40(53.3)\end{array}$} & \multirow{2}{*}{$\begin{array}{c}\text { Total } \\
75(38.5)\end{array}$} & \multirow{2}{*}{$\begin{array}{r}\text { p-value } \\
0.012\end{array}$} \\
\hline Duties & Preparation for & 1 & & & & & \\
\hline \multirow{27}{*}{$\begin{array}{l}\text { performed } \\
\text { in oral and } \\
\text { maxillofacial } \\
\text { surgery }\end{array}$} & tooth extraction & $2 \sim 4$ & $7(22.6)$ & $30(33.7)$ & $19(25.3)$ & $56(28.7)$ & \\
\hline & (y) & $\geq 5$ & $13(41.9)$ & $26(29.2)$ & $15(20.0)$ & $54(27.7)$ & \\
\hline & & $\begin{array}{l}\text { Likely to perform } \\
\text { in the future }\end{array}$ & $3(9.7)$ & $6(6.7)$ & $1(1.3)$ & $10(5.1)$ & \\
\hline & Preparation for & 1 & $8(25.8)$ & $14(15.7)$ & $27(36.0)$ & $49(25.1)$ & 0.012 \\
\hline & biopsy (y) & $2 \sim 4$ & $5(16.1)$ & $15(16.9)$ & $13(17.3)$ & $33(16.9)$ & \\
\hline & & $\geq 5$ & $11(35.5)$ & $18(20.2)$ & $10(13.3)$ & $39(20.0)$ & \\
\hline & & $\begin{array}{l}\text { Likely to perform } \\
\text { in the future }\end{array}$ & 7 (22.6) & $42(47.2)$ & $25(33.3)$ & 74 (37.9) & \\
\hline & Assistance for & 1 & $7(22.6)$ & $24(27.0)$ & $29(38.7)$ & $60(30.8)$ & 0.012 \\
\hline & minor oral & $2 \sim 4$ & $8(25.8)$ & $24(27.0)$ & $28(37.3)$ & $60(30.8)$ & \\
\hline & surgery (y) & $\geq 5$ & $12(38.7)$ & $21(23.6)$ & $14(18.7)$ & $47(24.1)$ & \\
\hline & & $\begin{array}{l}\text { Likely to perform } \\
\text { in the future }\end{array}$ & $4(12.9)$ & $20(22.5)$ & $4(5.3)$ & $28(14.4)$ & \\
\hline & Management of & 1 & $6(19.4)$ & 7 (7.9) & $13(17.3)$ & $26(13.3)$ & $<0.001$ \\
\hline & patients with & $2 \sim 4$ & $4(12.9)$ & $8(9.0)$ & $23(30.7)$ & $35(17.9)$ & \\
\hline & cleft lip and & $\geq 5$ & $9(29.0)$ & $11(12.4)$ & $9(12.0)$ & $29(14.9)$ & \\
\hline & palate $(\mathrm{y})$ & $\begin{array}{l}\text { Likely to perform } \\
\text { in the future }\end{array}$ & $12(38.7)$ & $63(70.8)$ & $30(40.0)$ & $105(53.8)$ & \\
\hline & Management of & 1 & $5(16.1)$ & $6(6.7)$ & $12(16.0)$ & $23(11.8)$ & $<0.001$ \\
\hline & maxillofacial & $2 \sim 4$ & $5(16.1)$ & $5(5.6)$ & $21(28.0)$ & $31(15.9)$ & \\
\hline & reconstruction & $\geq 5$ & $8(25.8)$ & $5(5.6)$ & $7(9.3)$ & $20(10.3)$ & \\
\hline & patients (y) & $\begin{array}{l}\text { Likely to perform } \\
\text { in the future }\end{array}$ & 13 (41.9) & $73(82.0)$ & $35(46.7)$ & $121(62.1)$ & \\
\hline & Management of & 1 & $5(16.1)$ & $4(4.5)$ & $13(17.3)$ & $22(11.3)$ & $<0.001$ \\
\hline & patients with & $2 \sim 4$ & $4(12.9)$ & $6(6.7)$ & $22(29.3)$ & $32(16.4)$ & \\
\hline & oral cancer (y) & $\geq 5$ & $9(29.0)$ & $6(6.7)$ & $7(9.3)$ & $22(11.3)$ & \\
\hline & & $\begin{array}{l}\text { Likely to perform } \\
\text { in the future }\end{array}$ & $13(41.9)$ & $73(82.0)$ & $33(44.0)$ & $119(61.0)$ & \\
\hline & Suture and & 1 & $4(12.9)$ & $10(11.2)$ & $14(18.7)$ & $28(14.4)$ & 0.073 \\
\hline & stitch-out (y) & $2 \sim 4$ & $5(16.1)$ & $20(22.5)$ & $25(33.3)$ & $50(25.6)$ & \\
\hline & & $\geq 5$ & $8(25.8)$ & $12(13.5)$ & $13(17.3)$ & $33(16.9)$ & \\
\hline & & $\begin{array}{l}\text { Likely to perform } \\
\text { in the future }\end{array}$ & $14(45.2)$ & $47(52.8)$ & $23(30.7)$ & $84(43.1)$ & \\
\hline Total & & & $31(15.9)$ & 89 (45.6) & $75(38.5)$ & $195(100.0)$ & \\
\hline
\end{tabular}

Values are presented as number (\%).

preparation for biopsy among different workplaces with $\geq 5$ years, likely to perform in the future, and 1 year being the most common response for university hospitals, dental hospitals, and dental clinics, respectively $(\mathrm{p}<0.05)$.

Assistance for minor oral surgery was performed most often by those with work experience of 1 year and $2 \sim 4$ years $(30.8 \%$ each), followed in order by $\geq 5$ years (24.1\%) and likely to perform in the future (14.4\%). With respect to workplace, there were significant differences in who most often performed assistance for minor oral surgery among different workplaces with $\geq 5$ years; 1 year and 2 4 years; and 1 year being the most common response for university hospitals, dental hospitals, and dental clinics, respectively $(\mathrm{p}<0.05)$.

For management of patients with cleft lip and palate, the most common response was likely to perform in the future (53.8\%), followed in order by $2 \sim 4$ years $(17.9 \%), \geq 5$ years $(14.9 \%)$, and 1 year $(13.3 \%)$. With respect to 
workplace, there were significant differences in who most often performed management of patients with cleft lip and palate among different workplaces with likely to perform in the future being the common response for university hospitals and dental hospitals and $2 \sim 4$ years being the common response for dental clinics $(\mathrm{p}<0.001)$.

For management of maxillofacial reconstruction patients, the most common response was likely to perform in the future $(62.1 \%)$, followed in order by $2 \sim 4$ years (15.9\%), 1 year $(11.8 \%)$, and $\geq 5$ years $(10.3 \%)$. With respect to workplace, likely to perform in the future was the most common response for university hospitals, dental hospitals, and dental clinics, with especially high frequency shown in dental hospitals. Moreover, this duty being performed by those with experience of $\geq 5$ years was higher in university hospitals than other workplaces, while duty performed by those with experience of $2 \sim 4$ years was higher in dental clinics than other workplaces. The results showed significant differences among workplaces $(\mathrm{p}<0.001)$.

For management of patients with oral cancer, the most common response was likely to perform in the future (61.0\%), followed in order by $2 \sim 4$ years $(16.4 \%)$ and 1 year and $\geq 5$ years $(11.3 \%$ each $)$. With respect to workplace, likely to perform in the future was the most common response for university hospitals, dental hospitals,

Table 5. Duties Performed in Dental Implant Treatment

\begin{tabular}{|c|c|c|c|c|c|c|c|}
\hline \multicolumn{3}{|c|}{ Division } & \multirow{2}{*}{$\begin{array}{c}\begin{array}{c}\text { University } \\
\text { hospital level }\end{array} \\
6(19.4)\end{array}$} & \multirow{2}{*}{$\begin{array}{c}\begin{array}{c}\text { Dental hospital } \\
\text { level }\end{array} \\
20(22.5)\end{array}$} & \multirow{2}{*}{$\begin{array}{c}\text { Dental clinics } \\
30(40.0)\end{array}$} & \multirow{2}{*}{$\begin{array}{c}\text { Total } \\
56(28.7)\end{array}$} & \multirow{2}{*}{$\begin{array}{r}\text { p-value } \\
0.001\end{array}$} \\
\hline Duties & Understanding dental & 1 & & & & & \\
\hline performed & implants (y) & $2 \sim 4$ & $8(25.8)$ & $29(32.6)$ & $28(37.3)$ & $65(33.3)$ & \\
\hline in dental & & $\geq 5$ & $15(48.4)$ & $24(27.0)$ & $15(20.0)$ & $54(27.7)$ & \\
\hline $\begin{array}{l}\text { implant } \\
\text { treatment }\end{array}$ & & $\begin{array}{l}\text { Likely to perform } \\
\text { in the future }\end{array}$ & $2(6.5)$ & $16(18.0)$ & $2(2.7)$ & $20(10.3)$ & \\
\hline & \multirow{4}{*}{$\begin{array}{l}\text { Preparation for dental } \\
\text { implant surgery }(\mathrm{y})\end{array}$} & 1 & 7 (22.6) & $23(25.8)$ & $34(45.3)$ & $64(32.8)$ & 0.001 \\
\hline & & $2 \sim 4$ & $7(22.6)$ & $25(28.1)$ & $25(33.3)$ & $57(29.2)$ & \\
\hline & & $\geq 5$ & $13(41.9)$ & $23(25.8)$ & $14(18.7)$ & $50(25.6)$ & \\
\hline & & $\begin{array}{l}\text { Likely to perform } \\
\text { in the future }\end{array}$ & $4(12.9)$ & $18(20.2)$ & $2(2.7)$ & $24(12.3)$ & \\
\hline & \multirow{4}{*}{$\begin{array}{l}\text { Preparation for bone } \\
\text { augmentation for } \\
\text { dental implant (y) }\end{array}$} & 1 & $6(19.4)$ & $13(14.6)$ & $25(33.3)$ & $44(22.6)$ & $<0.001$ \\
\hline & & $2 \sim 4$ & 7 (22.6) & $22(24.7)$ & $28(37.3)$ & $57(29.2)$ & \\
\hline & & $\geq 5$ & $13(41.9)$ & $21(23.6)$ & $14(18.7)$ & 48 (24.6) & \\
\hline & & $\begin{array}{l}\text { Likely to perform } \\
\text { in the future }\end{array}$ & $5(16.1)$ & $33(37.1)$ & 8 (10.7) & $46(23.6)$ & \\
\hline & \multirow{4}{*}{$\begin{array}{l}\text { Preparation of dental } \\
\text { implant prostheses } \\
\text { (y) }\end{array}$} & 1 & $5(16.1)$ & $18(20.2)$ & 29 (38.7) & $52(26.7)$ & $<0.001$ \\
\hline & & $2 \sim 4$ & $9(29.0)$ & $22(24.7)$ & $30(40.0)$ & $61(31.3)$ & \\
\hline & & $\geq 5$ & $14(45.2)$ & $23(25.8)$ & $15(20.0)$ & $52(26.7)$ & \\
\hline & & $\begin{array}{l}\text { Likely to perform } \\
\text { in the future }\end{array}$ & $3(9.7)$ & $26(29.2)$ & $1(1.3)$ & $30(15.4)$ & \\
\hline & \multirow{4}{*}{$\begin{array}{l}\text { Management of } \\
\text { dental implant } \\
\text { equipment (y) }\end{array}$} & 1 & $4(12.9)$ & $9(10.1)$ & $22(29.3)$ & $35(17.9)$ & $<0.001$ \\
\hline & & $2 \sim 4$ & $10(32.3)$ & $23(25.8)$ & $33(44.0)$ & $66(33.8)$ & \\
\hline & & $\geq 5$ & $14(45.2)$ & $23(25.8)$ & $15(20.0)$ & $52(26.7)$ & \\
\hline & & $\begin{array}{l}\text { Likely to perform } \\
\text { in the future }\end{array}$ & $3(9.7)$ & $34(38.2)$ & $5(6.7)$ & $42(21.5)$ & \\
\hline & \multirow{4}{*}{$\begin{array}{l}\text { Oral hygiene care for } \\
\text { dental implant } \\
\text { patients (y) }\end{array}$} & 1 & $5(16.1)$ & $17(19.1)$ & $22(29.3)$ & $44(22.6)$ & 0.001 \\
\hline & & $2 \sim 4$ & $9(29.0)$ & $28(31.5)$ & $36(48.0)$ & $73(37.4)$ & \\
\hline & & $\geq 5$ & $14(45.2)$ & $24(27.0)$ & $15(20.0)$ & $53(27.2)$ & \\
\hline & & $\begin{array}{l}\text { Likely to perform } \\
\text { in the future }\end{array}$ & $3(9.7)$ & $20(22.5)$ & $2(2.7)$ & $25(12.8)$ & \\
\hline Total & & & $31(15.9)$ & $89(45.6)$ & $75(38.5)$ & $195(100.0)$ & \\
\hline
\end{tabular}

Values are presented as number (\%). 
and dental clinics, with especially high frequency shown in dental hospitals. Moreover, this duty being performed by those with experience of $\geq 5$ years was higher in university hospitals than other workplaces, while duty performed by those with experience of $2 \sim 4$ years was higher in dental clinics than other workplaces. The results showed significant differences among workplaces $(\mathrm{p}<$ 0.001).

For suture and stitch-out, the most common response was likely to perform in the future (43.1\%), followed in order by $2 \sim 4$ years $(25.6 \%), \geq 5$ years $(16.9 \%)$, and 1 year (14.4\%). With respect to workplace, likely to perform in the future was the most common response for university hospitals and dental hospitals and $2 \sim 4$ years was the most common response for dental clinics, but the differences were not significant.

\section{Duties performed in dental implant treatment}

Table 5 shows the results of duties performed by dental hygienists in dental implant treatment.

For understanding dental implants, the most common response was $2 \sim 4$ years (33.3\%), followed in order by 1 year $(28.7 \%), \geq 5$ years $(27.7 \%)$, and likely to perform in the future (10.3\%). With respect to workplace, there were significant differences in understanding dental implants among different workplaces with $\geq 5$ years, $2 \sim 4$ years, and 1 year being the most common response for university hospitals, dental hospitals, and dental clinics, respectively $(\mathrm{p}<0.01)$.

Preparation for dental implant surgery was performed most often by those with work experience of 1 year (32.8\%), followed in order by $2 \sim 4$ years $(29.2 \%), \geq 5$ years (25.6\%), and likely to perform in the future (12.3\%). With respect to workplace, there were significant differences in who most often performed preparation for dental implant surgery among different workplaces with $\geq 5$ years, $2 \sim 4$ years, and 1 year being the most common response for university hospitals, dental hospitals, and dental clinics, respectively $(\mathrm{p}<0.01)$.

Preparation for bone augmentation for dental implant was performed most often by those with work experience of $2 \sim 4$ years $(29.2 \%)$, followed in order by $\geq 5$ years (24.6\%), likely to perform in the future (23.6\%), and 1 year $(22.6 \%)$. With respect to workplace, there were significant differences in who most often performed preparation for bone augmentation for dental implant among different workplaces with $\geq 5$ years, likely to perform in the future, and 2 4 years being the most common response for university hospitals, dental hospitals, and dental clinics, respectively $(\mathrm{p}<0.001)$.

Preparation of dental implant prostheses was performed most often by those with work experience of $2 \sim 4$ years (31.3\%), followed in order by 1 year and $\geq 5$ years $(26.7 \%$ each) and likely to perform in the future (15.4\%). With respect to workplace, there were significant differences in who most often performed preparation of dental implant prostheses among different workplaces with $\geq 5$ years, likely to perform in the future, and $2 \sim 4$ years being the most common response for university hospitals, dental hospitals, and dental clinics, respectively $(\mathrm{p}<0.001)$.

Management of dental implant equipment was performed most often by those with work experience of $2 \sim 4$ years (33.8\%), followed in order by $\geq 5$ years (26.7\%), likely to perform in the future $(21.5 \%)$, and 1 year (17.9\%). With respect to workplace, there were significant differences in who most often performed management of dental implant equipment among different workplaces with $\geq 5$ years, likely to perform in the future, and $2 \sim 4$ years being the most common response for university hospitals, dental hospitals, and dental clinics, respectively $(\mathrm{p}<0.001)$.

Oral hygiene care for dental implant patients was performed most often by those with work experience of $2 \sim 4$ years $(37.4 \%)$, followed in order by $\geq 5$ years (27.2\%), 1 year (22.6\%), and likely to perform in the future $(12.8 \%)$. With respect to workplace, there were significant differences in who most often performed oral hygiene care for dental implant patients among different workplaces with $\geq 5$ years being the most common responses for university hospitals and $2 \sim 4$ years being the most common response for dental hospitals and dental clinics $(\mathrm{p}<0.01)$.

\section{Discussion}

The present study focused on conservation dentistry, pediatric dentistry, prosthodontics, oral and maxillofacial 
surgery, and dental implant treatment, which make up some of the fields covered by dental hygiene practice, in conducting job survey and analysis by clinical experience and workplace to establish basic data needed for legislation and policy utilization for realization of legal scope of dental hygienists.

With respect to duties performed in conservation dentistry and pediatric dentistry, the study by Han et al. ${ }^{8)}$ reported that the most common opinion was that such duties could be performed after gaining at least $1 \sim 3$ years of experience, and specifically, the most common response for rubber dam isolation was $\geq 1$ year (59.9\%). In the present study, the most common response for rubber dam isolation was 1 year with $29.7 \%$. Despite the differences in the response rates, the results indicated that this duty could be performed with little clinical experience.

The study by Han et al. ${ }^{8)}$ found that the respondents expressed the opinion that performing matrix band technique, pulp vitality test, and teeth whitening treatment were not duties of dental hygienists. In the present study, the most common response for performing matrix band technique and pulp vitality test was likely to perform in the future. Meanwhile, teeth whitening treatment was performed most often by those with $2 \sim 4$ years of experience in university hospitals and dental clinics and those likely to perform in the future in dental hospitals, showing significant differences $(\mathrm{p}<0.001)$. Generally, this duty could be performed with $2 \sim 4$ years of experience and the response of likely to perform in the future being most common in dental hospitals may be due to division of departments in such dental hospitals.

In the study by Han et al. ${ }^{8}$, the most common response for assistance for primary tooth extraction, assistance for prosthodontic treatment of primary teeth, preparation for dental fenestration, preventive orthodontic treatment training, and assistance for behavior management of pediatric patients was that they are duties that could be performed with $\geq 1$ year of experience. The findings in the present study showed differences, where the equally most common responses for assistance for primary tooth extraction and assistance for prosthodontic treatment of primary teeth being 1 year and $2 \sim 4$ years of experience, while the most common response for preparation for dental fenestration, preventive orthodontic treatment training, and assistance for behavior management of pediatric patients was $2 \sim 4$ years of experience. With respect to workplace, there were significant differences with $\geq 5$ years, likely to perform in the future, and 1 year and $2 \sim 4$ years being the most common response for university hospitals, dental hospitals, and dental clinics, respectively $(\mathrm{p}<0.001)$.

With respect to duties performed in prosthodontics, the study by Han et al. ${ }^{8)}$ reported that the most common response for gingival retraction, assistance for fixed prosthodontic treatment, assistance for removable prosthodontic treatment, application/removal of prosthesis, and management of prosthesis was $\geq 1$ year of experience, whereas the most common response for fabrication of temporary crowns, fabrication of individual trays, and dental shade selection was $\geq 3$ years of experience. In the present study, the most common response for gingival retraction, assistance for fixed prosthodontic treatment, assistance for removable prosthodontic treatment, application/ removal of prosthesis, and management of prosthesis was $\geq 1$ year of experience. For fabrication/installation of temporary crowns and fabrication of individual trays, the most common response was $2 \sim 4$ years for dental hospitals and dental clinics and $\geq 5$ years for university hospitals. Accordingly, there appears to be a gap between the clinical reality and separation of duties with dental technicians, indicating the desperate need for amending the Medical Technologists, Etc. Act to reflect the reality of fabrication of temporary crowns and individual trays.

A study by Kim and Shin ${ }^{9)}$ reported that among the treatment assistance duties, topical anesthesia, infiltration anesthesia, rubber dam installation/removal, temporary fillings, fabrication of temporary teeth, impression taking, fabrication of models, fabrication of whitening trays, whitening treatment procedure, gingival retraction, postoperative care, and installation of prosthesis were performed at the highest rate in dental clinics, while such work was performed at a lower rate in dental hospitals and university hospitals $(\mathrm{p}<0.001)$. The findings in the present study also showed that the performance of overall duties was most aggressive, relative to clinical experience, in dental clinics. According to a survey of 419 dentists by 
the Korean Dental Hygienists Association in 2017, the duties that dental hygienists performed during treatment consisted of temporary fillings and installation/removal of prosthesis, which was similar to the findings in the present study ${ }^{8,10)}$. Therefore, the Medical Technologists, Etc. Act should be amended to include broad work scope instead of being an ambiguous law that relies on authoritative interpretation by the Ministry of Health and Welfare whenever a problem arises.

With respect to duties performed in oral and maxillofacial surgery, the study by Han et al. ${ }^{8)}$ reported that the most common response for preparation for tooth extraction, preparation for biopsy, and assistance for minor oral surgery was $\geq 1$ year of experience, while the most common response for management of patients with cleft lip and palate, management of maxillofacial reconstruction patients, and management of patients with oral cancer was $\geq 3$ years of experience. For suture and stitch-out, there was a high response rate indicating that suture and stitch-out are not duties for dental hygienists. In the present study, the most common response for preparation for tooth extraction was 1 year, while the equally most common responses for assistance for minor oral surgery were 1 year and $2 \sim 4$ years. For management of patients with cleft lip and palate, management of maxillofacial reconstruction patients, and management of patients with oral cancer, the most common response was likely to perform in the future for university hospitals, dental hospitals, and dental clinics, followed by $2 \sim 4$ years with a significant difference $(p<0.001)$. For suture and stitch-out, the most common response was likely to perform in the future for university hospitals and dental hospitals and $2 \sim 4$ years for dental clinics, but the difference was not significant.

With respect to duties performed in dental implant treatment, the study by Han et al. ${ }^{8)}$ reported that the most common response for understanding dental implants, preparation for dental implant surgery, preparation for bone augmentation for dental implant, preparation of dental implant prostheses, and management of dental implant equipment was $\geq 1$ year of experience. In the present study, only preparation for dental implant surgery was found to be a duty that could be performed with 1 year of experience, while all others were found to be performed with $2 \sim 4$ years of experience. Therefore, it is believed that there is the need to revise laws with more specific and expanded interpretation of the field of dental implant treatment.

With respect to work place, the most common response for most duties was $\geq 5$ years, likely to perform in the future, and $2 \sim 4$ years for university hospitals, dental hospitals, and dental clinics, respectively, showing significant differences.

In conclusion, analysis of duties actually performed in dental practice, focusing on conservation dentistry, pediatric dentistry, prosthodontics, oral and maxillofacial surgery, and dental implant treatment, showed that most of the duties were currently being performed with some difference in years of experience or are likely to be performed in the future by dental hygienists. Investigation by type of workplace showed that most of the duties were performed by dental hygienists with $\geq 5$ years of experience in university hospitals, whereas dental hygienists with $2 \sim 4$ years of experience were performing more diverse and difficult duties in dental clinics. In dental hospitals, dental hygienists with $2 \sim 4$ years of experience were able to perform more diverse duties, while likely to perform in the future was the most common response, perhaps due to differences in some duties depending on the department. Such findings showed differences with the limitations of the study.

In a study by Lee et al. ${ }^{11)}$, both dentists and dental hygienists reported that specific items that needed to be expanded within the work scope of dental hygienists were fabrication and installation of temporary crowns; assistance for surgical operation, procedures, and treatment; and general treatment assistance. Based on the findings in the present study, it was revealed that there is a need to revise the overall assistance work by dental hygienists in dentistry according to actual clinical practice by analyzing the work scope and duties of dental hygienists. Among these, assistance for oral surgery operation and procedures, which has been plagued by much dispute, was being performed at a high rate by dental hygienists with 1 year and $2 \sim 4$ years of experience in dental hospitals and dental clinics, while most of the duties were being performed by 
dental hygienists with $\geq 5$ years of experience in university hospitals, which indicated that territorial disputes with nursing assistants are very far apart from the reality within the treatment room.

Based on these results, it is determined that the work scope regarding dental treatment assistance is very broad, but the duties of dental hygienists specified in the current Enforcement Decree of the Medical Technologists, Etc. Act amount to just a simple list of items and are far from the reality. The removal of legal stipulation about medical assistance has caused endless disputes in clinical practice. The reality of medical assistance during surgical operations and various procedures currently being performed no longer being legally protected directly contradicts the actual needs and demands in clinical dental practice ${ }^{12-15)}$. The work scope of nursing assistants working in dentistry is just as unclear. A review of authoritative interpretations that the Ministry of Health and Welfare has made to date regarding the work scope of nursing assistants showed that the work scope of nursing assistants may include treatment assistance work that could be performed with specific instruction or guidance from a physician ${ }^{16)}$. In a study by Choi et al. ${ }^{17)}$, there was a high response rate among dental hygienists indicating that the amended Medical Technologists, Etc. Act is inadequate and ineffective with respect to division of roles in clinical practice. Failure to reflect such reality in legal amendments is leading to legal disputes. Accordingly, the time has come for not simply neglecting such unrealistic problem, but quickly establishing legal and institutional measures that accurately reflect the actual clinical work for realization of work scope. Moreover, research and implementation of calculation of insurance fee for work performed by dental hygienists must also take place.

Continued research is needed for various fields, in addition to the fields investigated in the present study, while establishment of more fundamental and institutional policies are needed for realization of work scope of dental hygienists and alleviation of conflict between job roles. Since it is believed that consistent and systematic research and discussions must continue above all else, follow-up studies on fields not covered by the present study are planned for the future.
The present study had some limitations, including the following. The questionnaire survey was conducted on some dental hygienists working in university hospitals, dental hospitals, and dental clinics that were convenience sampled. The study also investigated only some of various duties performed by dental hygienists. Therefore, there are limitations in generalizing the results of this study. However, since it is necessary to create an environment that allows dental hygienists working in dental institutions to provide the best possible quality of dental care service, while being guaranteed of their legal scope and professionalism, the present study attempted to establish the basic data for division of duties performed in dentistry according to degree of difficulty and establishment of policies for specific legal scope, which can be viewed as the significance of the present study.

\section{Notes}

\section{Conflict of interest}

No potential conflict of interest relevant to this article was reported.

\section{Ethical approval}

The study was approved by the Institutional Review Board of Shinhan University (IRB No. SHIRB-201904HR-089-02).

\section{Author contributions}

Conceptualization, Data acquisition, Formal analysis, Funding, Supervision, Writing-original draft, Writingreview \& editing: Mi-Sook Yoon.

\section{ORCID}

Mi-Sook Yoon, https://orcid.org/0000-0001-8029-128X

\section{Acknowledgements}

This study was supported by research fund from Shinhan University University (2019). 


\section{References}

1. Park MS, Kim HJ, Bae SM, et al.: Introduction to dental hygiene. 3rd ed. DaehanNarae Publishing Inc., Seoul, pp.4-60, 2020.

2. Korea Ministry of Government Legislation: Enforcement decree of the act on medical engineers, etc. [enforcement 2019. 7. 2.] [Presidential decree No.29950, other law revision]. Article 2 clause 1 no. 6 medical engineers. Health and medical information manager and optometrist's scope of work, 2020. Retrieved October 5, 2020, from https://www. moleg.go.kr/index.es?sid=a1 (2020).

3. Shin SJ, Son JH, Choi YK, Ryu DY, Ma DS: A study on the estimation of the number of dental hygienist and their practice. J Dent Hyg Sci 7: 25-30, 2007.

4. Retrieved September 23, 2020, from http://www.fnnews. com/print/201502021341277453(2015).

5. Retrieved September 24, 2020, from http://dentalkoo.com/ archives/8444(2018).

6. Retrieved September 24, 2020, from http://dentalkoo.com/ archives/8492(2018).

7. Park JL, Kang KH, Kim SA, et al.: 2nd job analysis for dental hygienists. Korea Health Personnel Licensing Examination Institute, Seoul, pp.116-171, 2012.

8. Han YK, Kim EK, Kim SH, et al.: A study on the dentist's opinion on the actual work and legal work of dental hygienists. Korean Dental Hygienist Association, Seoul, Daejeon Health University Industry-Academic Cooperation Group, Daejeon, pp.1- 120, 2017.

9. Kim YS, Shin MW: A study on the current state and weight of dental hygienists' works. J Korean Soc Dent Hyg 8: 161-175, 2008.

10. Lee HJ, Shin SJ, Bae SM, Shin BM: Issues and challenges of dental hygienist workforce policy in Korea. J Korea Contents Assoc 19: 409-423, 2019. https://doi.org/10.5392/JKCA.2019.19.02.409

11. Lee HJ, Shin SJ, Bae SM, Shin BM: A survey of dentists and dental hygienists on dental team composition and work assignments. J Korean Dent Hyg Sci 2: 51-62, 2019.

12. Jeong JH, Mun SJ, Bae SS, Kim SK, Noh HJ: A study on the dental hygienists' legal scope of clinical practice. J Korean Soc Dent Hyg 19: 207-219, 2019. https://doi.org/10.13065/jksdh.20190019

13. Chung WG, Noh HJ, Kim NH, Mun SJ, Jeon HS, Han SY: The history of dental hygiene education in Korea. DaehanNarae Publishing Inc., Seoul, pp.30-211, 2015.

14. Ahn YS, Shin SJ, Jung SH, Lee YS, Lim DS: Comparison of job description and turnover trend among dental hygienists and assistant nurses in dental clinics. J Korean Acad Oral Health 30: 305-315, 2006.

15. Cho EJ, Lim SR: A qualitative research on conflict experiences of clinical dental hygienists. J Dent Hyg Sci 16: 449-457, 2016. https://doi.org/10.17135/jdhs.2016.16.6.449

16. Retrieved October 15, 2020, from http://www.dentalarirang. com/news/articleView.html?idxno=8371(2014).

17. Choi YR, Seo HY, Ryu EJ, Choi EM: Dental hygienists' awareness of medical technician jurisprudence. J Dent Hyg Sci 16: 495-501, 2016. https://doi.org/10.17135/jdhs.2016.16.6.495 